\title{
New record of Stolzmann's crab-eating rat Ichthyomys stolzmanni (Rodentia: Cricetidae) in Ecuador
}

\author{
Jorge Brito $^{1 *}$, Germán Tenecota² y Glenda M. Pozo-Zamora ${ }^{1}$
}

\footnotetext{
${ }^{1}$ Museo Ecuatoriano de Ciencias Naturales del Instituto Nacional de Biodiversidad, División de Mastozoología. Calle Rumipamba 341 y Avenida de Los Shyris, Quito 17-07-8976, Ecuador. E-mail: jorgeyakuma@yahoo.es (JB), glenda.pozo@yahoo.es (GMPZ)

${ }^{2}$ Guardaparque del Parque Nacional Sangay, zona baja. Macas, Ecuador. E-mail: german.tenecota@ambiente.gob.ec

* Corresponding author
}

\begin{abstract}
Stolzmann's crab-eating rat Ichthyomys stolzmanni is known from six locaties, two of those in the eastern slopes of Ecuador and four in southeastern Peru. We recorded a male specimen in the Jurumbuno River, on the eastern slopes of Ecuador at the province of Morona Santiago. We described the body and cranial characteristics, which are within the range known for the species, except that the tail is bicolored to the medial portion and the rear half is uniformly dark. The digestive tract contained traces of insects (Corydalus sp.), shrimps (Macrobrachium sp.), and isopods (Artystone trisibia); the latter parasitizes fish, and this is the first report of this parasite in the diet of I. stolzmanni. Our record in the Jurumbuno River is the third locality in Ecuador for the species studied, 40 years after its previous capture.

Key words: distribution; Ichthyomyini; Sangay National Park; southeastern Ecuador.

Registramos un individuo macho en el río Jurumbuno, en la vertiente oriental del Ecuador, provincia de Morona Santiago. Describimos características corporales y craneanas, éstas se encuentran dentro del intervalo conocido para la especie, exceptuando la cola que es bicolor hasta la parte medial y la mitad posterior uniformemente oscura. El tracto digestivo contenía restos de insectos (Corydalus sp.), camarones (Macrobrachium sp.), e isópodos (Artystone trisibia), éste último parasita a peces y es encontrado por primera vez en la dieta de l. stolzmanni. Nuestro registro, en el río Jurumbuno, representa la tercera localidad en Ecuador luego de 40 años de su última captura.
\end{abstract}

๑ 2016 Asociación Mexicana de Mastozoología, www.mastozoologiamexicana.org

\section{Introduction}

The genus Ichthyomys encompasses four species of cricetid rodents adapted to the semi-aquatic life, which occur only in the Neotropics, from Panama to southern Peru, including northeastern Venezuela. The species of the genus Ichthyomys inhabit lowland and montane forests, and moors, in an altitudinal range of 214 to $3,526 \mathrm{~m}$ a.s.l., along streams, springs or artificial water courses such as ditches (Voss 1988; Pacheco and Ugarte-Núñez 2011; García et al. 2012; Santillán and Segovia 2013; Voss 2015). The genus feeds preferentially on shrimp, crabs, insect larvae, semi-aquatic cockroaches and fish (Thomas 1893; Voss et al. 1982; Pacheco and Ugarte-Núñez 2011; Santillán and Segovia 2013). Similarly, this rodent may be preyed upon by nocturnal birds of prey (Brito et al. 2015).

Ichthyomys stolzmanni is known only from two localities in the eastern slope of Ecuador (Anthony 1923; Voss 1988; Tirira 2011) and four from southeastern Peru (Thomas 1893; Voss 1988; Pacheco and Ugarte-Núñez 2011). The latest collection for Ecuador was carried out by A. Gardner in 1976 in Sabanilla, province of Zamora Chinchipe (Pacheco 2003; Tirira 2007). This specimen was determined (Pacheco 2003) as Ichthyomys hydrobates. However, Tirira (pers. comm.), based on the review of this specimen (USNM 513625, young male) that shows a markedly bicolored tail and was collected east of the Andes (Voss 2015), identified this specimen as I. stolzmanni. 
Historically, I. stolzmanni grouped two subspecies: I. s. orientalis inhabiting northern Ecuador, and I. s. stolzmanni from southern Peru (Cabrera 1961; Voss 1988). Only a single subspecies is currently recognized (Pacheco and Ugarte-Núñez 2011), because no phenotypic characteristics differentiate them, a proposal followed by Voss (2015).

In the present work we report a new locality for I. stolzmanni, which also implies an additional report 40 years after the previous collection in Ecuador, being the first reference for the province of Morona Santiago. The morphological and cranial measures of the specimen collected are reported, and the palmar and plantar structures are described; additionally, the stomach contents of this specimen are mentioned. The information about the characters described may be useful for future taxonomic, phylogenetic and ecological studies, while contributing relevant data to the protection of this poorly known species.

\section{Materials and Methods}

One specimen of I. stolzmanni was collected by Germán Tenecota on 29 March 2016, at Jurumbuno river (-2 $06^{\prime} 55.32^{\prime \prime}$ S, $-78^{\circ} 07^{\prime} 12.76^{\prime \prime}$ W, 1,300 m), Nueva Alianza sector, buffer zone of the Sangay National Park, province of Morona Santiago, Ecuador (Figure 1). The collection area belongs to the Eastern Subtropical plains (Albuja et al. 2012), in the Upano-Zamora ichtyogeographic zone (Barriga 2012). In the collection site, the Jurumbuno river measures approximately $12 \mathrm{~m}$ wide by $1 \mathrm{~m}$ deep (Figure 2). The specimen was caught with a 20-pound net with 20-mm mesh-size. Several fish species have been captured in the same site, including sardines (Astyanax spp.), curundas (Lebiasina elongata), bocachicos (Prochilodus nigricans), preñadillas (Astroblepus festae), carachamas (Chaetostoma breve), barbudos (Rhamdia quelen), viejas (Aequidens tetramerus) and chuvis (Crenicichla sp; F. Anaguano-Yancha, unpublished data).

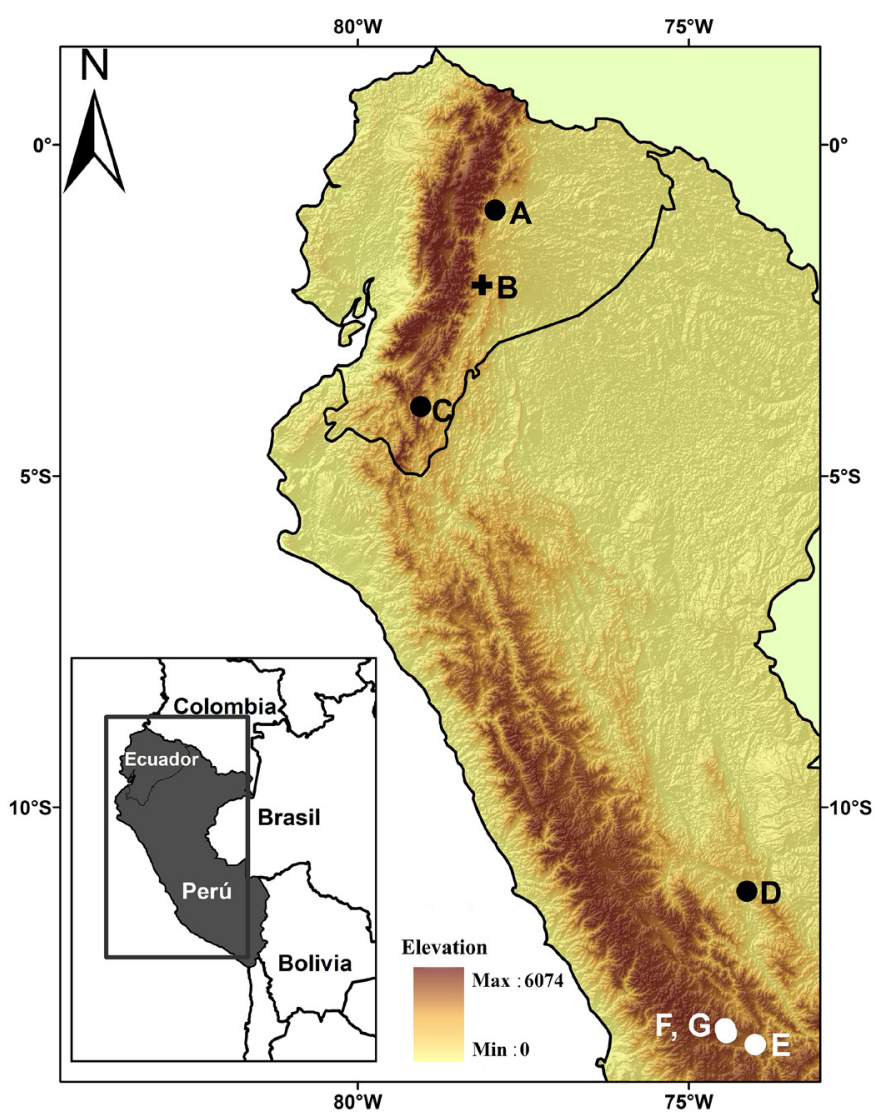

Figure 1. Record localities of Ichthyomys stolzmanni; Ecuador: $A=$ Tena, $B=$ Jurumbuno river, $C=$ Sabanilla (Anthony 1923; Voss 1988; Tirira 2007; this study); Peru: $\mathrm{D}=$ Chanchamayo, $\mathrm{E}=$ Ayacucho, $\mathrm{F}=$ The Bagrecito, $\mathrm{G}=$ Arizona (Thomas 1983; Pacheco and UgarteNúñez 2011). 
Figure 2. View of Jurumbuno river (1,300 m), habitat of Ichthyomys stolzmanni in Ecuador.

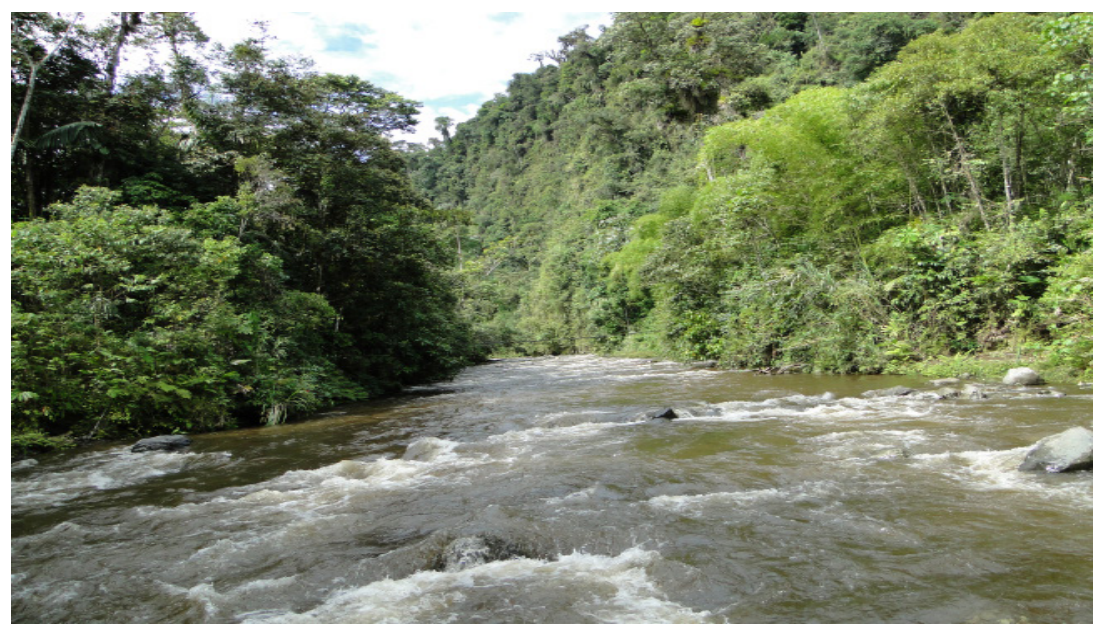

The reference specimen was deposited in the Mastozoology Division of the Museo Ecuatoriano de Ciencias Naturales, Quito, Ecuador (DMMECN 4,914), from which the skull was removed and cleaned with dermestid larvae; the body was preserved in $75 \%$ alcohol. Cranial measures were taken with a digital gauge to the nearest $0.1 \mathrm{~mm}$. The measures, body and cranial features were recorded following Voss (1988). Food items in the stomach contents were identified with a magnifying glass (Leica EZ4HD) at 35x.

Table 1. Measures of Ichthyomys stolzmanni specimens from Ecuador and Peru.

\begin{tabular}{|c|c|c|c|}
\hline & \multicolumn{2}{|r|}{ Ecuador } & Peru \\
\hline & $\begin{array}{c}\text { DMMECN } \\
4,914\end{array}$ & (Anthony 1923; Voss 1988) & (Thomas 1898; Pacheco and Ugarte-Núñez 2011) \\
\hline Age & $5 / \mathrm{c} / \mathrm{a}$ & $3-5 / 0, f / a$ & 2/o/a, 4/?/a, 2/o/a \\
\hline Sex & Males & 4 males 2 females & 2 females 1 undetermined \\
\hline Head-body length & 160 & - & - \\
\hline Tail length & 185 & - & 177 \\
\hline Hind foot length & 41 & $39.3 \pm 0.52(39-40) 6$ & $39 \pm 1.41(38-40) 2$ \\
\hline Ear length & 11 & $9.8 \pm 0.45(9-10) 5$ & $10 \pm 0(10-10) 2$ \\
\hline Condyle-incisor length & 35.4 & $33.6 \pm 1.27(32.2-35.2) 6$ & $29.87 \pm 4.57(26.64-33.1) 2$ \\
\hline Diastema length & 9.2 & $8.7 \pm 0.44(8.1-9.1) 6$ & $8.45 \pm 1.31(7.03-9.61) 3$ \\
\hline Upper molar series & 4.3 & $4.4 \pm 0.05(4.3-4.4) 6$ & $4.03 \pm 0.32(3.81-4.4) 3$ \\
\hline Incisive foramen length & 6.5 & $6.6 \pm 0.19(6.3-6.8) 6$ & $6.15 \pm 0.59(5.47-6.5) 3$ \\
\hline Incisor apex width & 2.2 & $2.2 \pm 0.08(2.1-2.3) 6$ & $1.92 \pm 0.23(1.66-2.1) 3$ \\
\hline Incisive foramen width & 1.8 & $2.0 \pm 0.16(1.8-2.2) 6$ & $2.29 \pm 0.23(2.02-2.44) 3$ \\
\hline Palate width & 2.9 & $3.0 \pm 0.21(2.7-3.3) 6$ & $2.90 \pm 0.41(2.49-3.3) 3$ \\
\hline Nasal length & 12.3 & $11.3 \pm 0.44(10.9-12.1) 6$ & $10.41 \pm 1.34(8.88-11.35) 3$ \\
\hline Nasal width & 4.1 & $3.9 \pm 0.23(3.6-4.2) 6$ & $3.85 \pm 0.45(3.34-4.2) 3$ \\
\hline Least interorbital constriction & 4.8 & $4.4 \pm 0.29(4.0-4.8) 6$ & $4.84 \pm 0.14(4.74-5) 3$ \\
\hline Bizygomatic width & 16.8 & $16.2 \pm 0.61(15.4-17.0) 6$ & 16 \\
\hline Cranial width & 13.8 & $14.3 \pm 0.16(14.1-14.6) 6$ & $13.45 \pm 1.06(12.07-14.2) 2$ \\
\hline Zygomatic plate width & 1.5 & $1.5 \pm 0.15(1.3-1.7) 6$ & $1.28 \pm 0.21(1.04-1.4) 3$ \\
\hline Upper first molar width & 1.4 & $1.6 \pm 0.05(1.5-1.6) 6$ & $1.49 \pm 1.10(1.41-1.6) 3$ \\
\hline Upper incisor length & 6.1 & $5.9 \pm 0.40(5.4-6.4) 5$ & $5.51 \pm 0.82(4.56-6) 3$ \\
\hline Upper incisor depth & 1.9 & $1.9 \pm 0.12(1.8-2.1) 6$ & $1.71 \pm 0.33(1.34-1.98) 3$ \\
\hline Width between occipital condyles & 9.7 & $9.0 \pm 0.17(8.8-9.2)$ & $8.96 \pm 0.76(8.42-9.5) 2$ \\
\hline Weight in grams & 140 & & \\
\hline
\end{tabular}




\section{Results}

The main body and cranial measures of the I. stolzmanni specimen from the Jurumbuno river (Table 1) are within the range known for the species (Voss 1988; Pacheco and Ugarte-Núñez 2011). The specimen DMMECN 4,914 shows a narrow skull and interorbital region, with obvious supraorbital foramen, carotid circulation pattern 3 (sensu Voss 1988), presence of the orbicular apophysis of the malleus (Figure 3) and leg longer than $39.0 \mathrm{~mm}$, all of which being diagnostic characters for this species (Voss 1988, 2015).

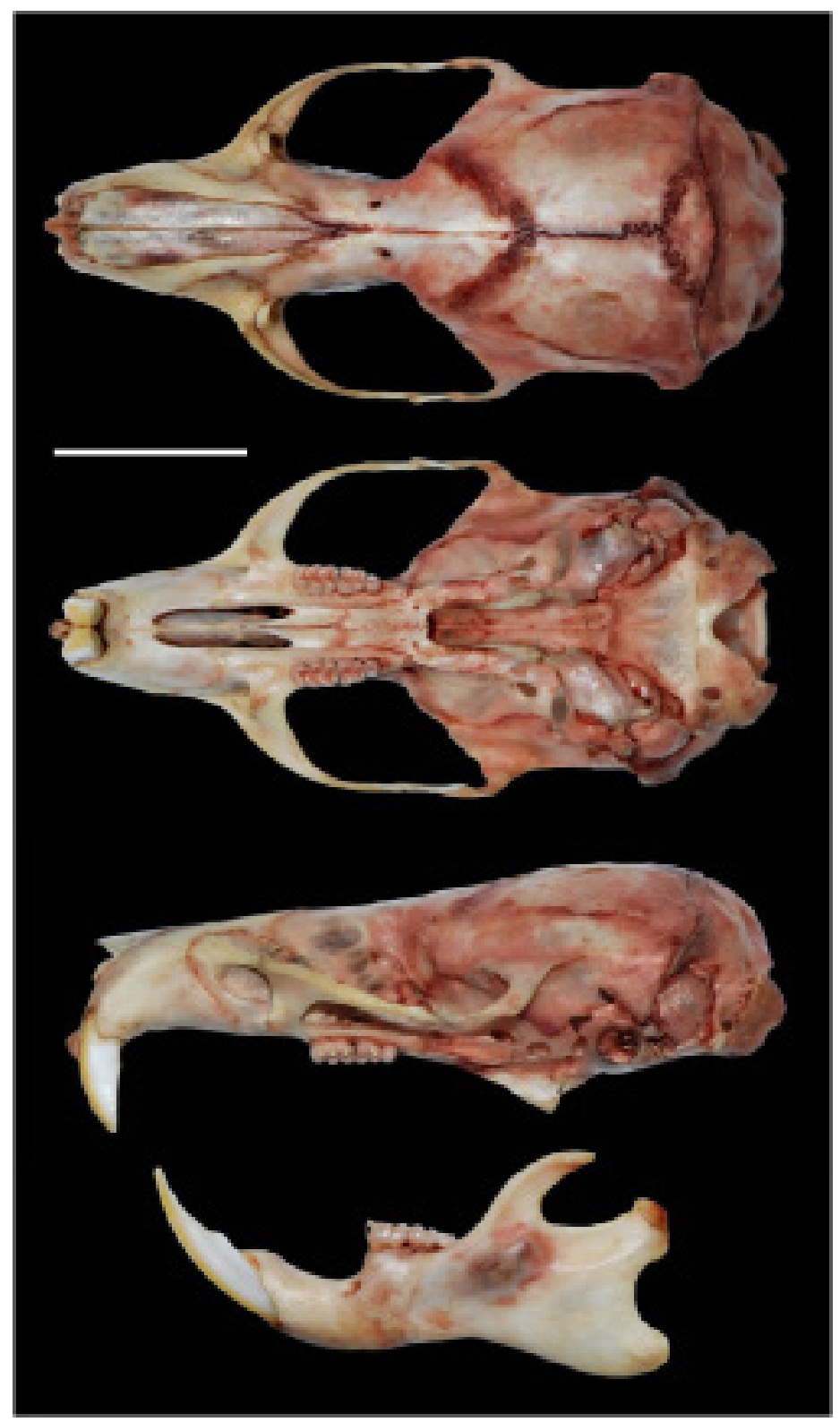

Figure 3. Dorsal (above), ventral (center) and lateral (bottom) view of the skull of Ichthyomys stolzmanni (DMMECN 4,914). Bar $=10 \mathrm{~mm}$.

Externally, the specimen shows the following features: coat with a dark brown color dorsally and whitish with yellowish shades ventrally (Figure 4); pectoral region with a dark brown strip; thick and short mistacial whiskers that do not surpass the shoulder when bended backwards. The tail, longer than the head-body length, is thick, robust and densely covered with hairs, dark brown dorsally, while ventrally it is whitish to the medial region and dark brown distally (Figure 4). The hairs at the tip of the tail protrude $7.0 \mathrm{~mm}$. 

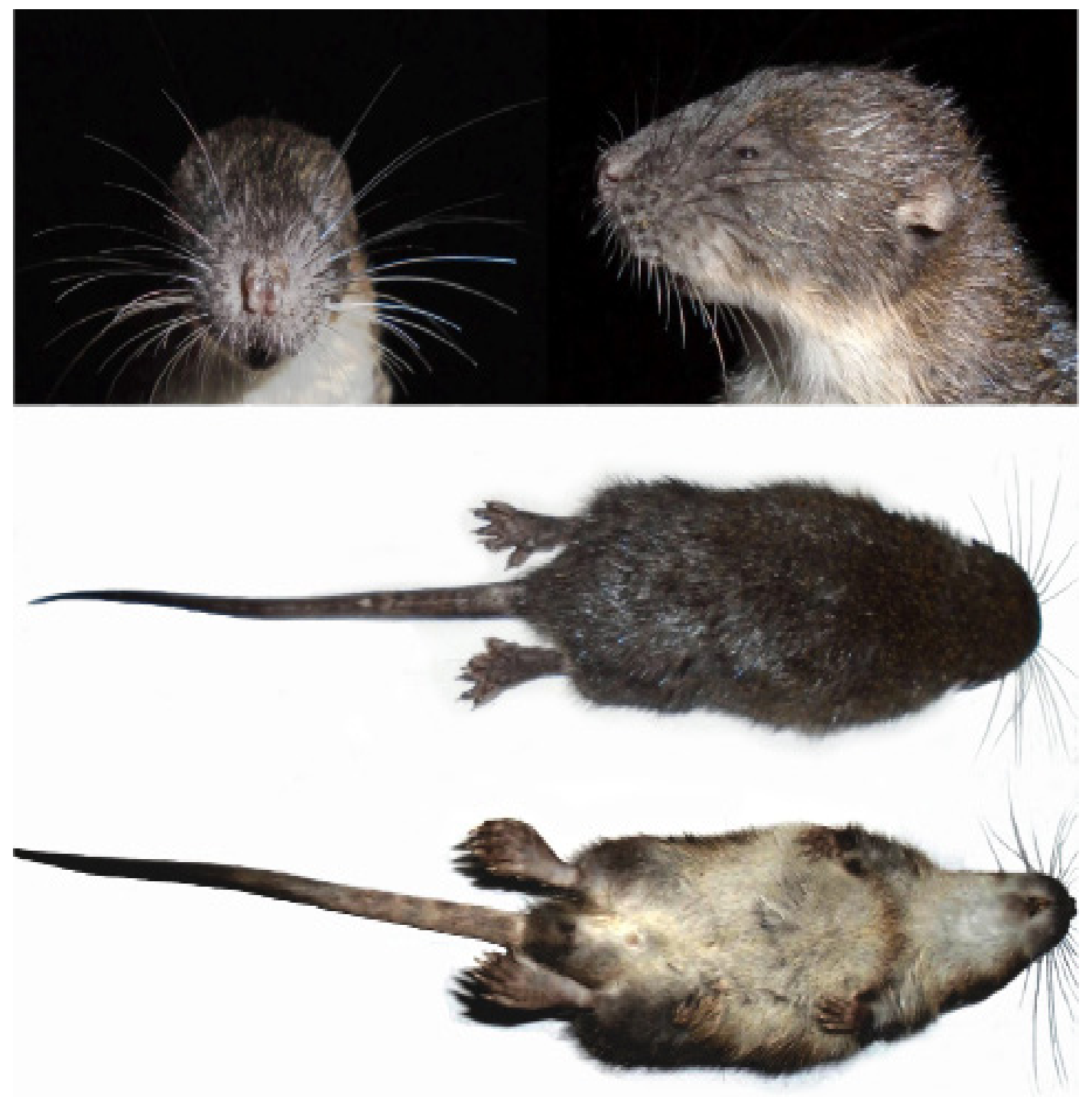

Figure 4. Front and lateral (above), dorsal (center) and ventral (bottom) view of the head of Ichthyomys stolzmanni (DMMECN 4,914); head-body length $160 \mathrm{~mm}$.

The front leg is medium-sized and thin; it has five fingers with claws, with the thumb being shortened with a short and rounded claw. The remaining fingers are relatively short, with enlarged and curved claws. Tufts of nail hairs cover $40 \%$ of the claws in the hands. The metacarpal region is whitish with long dark brown hairs. The palmar surface shows five pads: the thenar and hypothenar pads are enlarged and separated by a small space; the three interdigital pads share a similar size, approximately $50 \%$ of the thenar pad size (Figure 5).

The hind leg is relatively long and wide, with short nail tufts that cover $30 \%$ of the claws. The dorsal region of the foot is white, with short and medium black hairs, most noticeable at the outer edge. The dorsal surface of the phalanges is white with black hairs. Five plantar pads are present; the thenar tubercle is well developed and the hypothenar is absent. There is a wide space between the thenar pad and the first interdigital pad. Plantar surfaces are tuberculate. Digits are relatively short and wide. The outer edges of the foot and digits are bordered by fringes of hairs that measure $2.5 \mathrm{~mm}$ long. There are poorly developed interdigital membranes between fingers I - II and IV - V, while those between fingers II - III and III - IV grow beyond the first interphalangeal joint (Figure 5). The stomach and digestive tract contained remains of an arthropod (Corydalus sp.), a shrimp (Macrobrachium sp.) and an isopod (Artystone trisibia). 


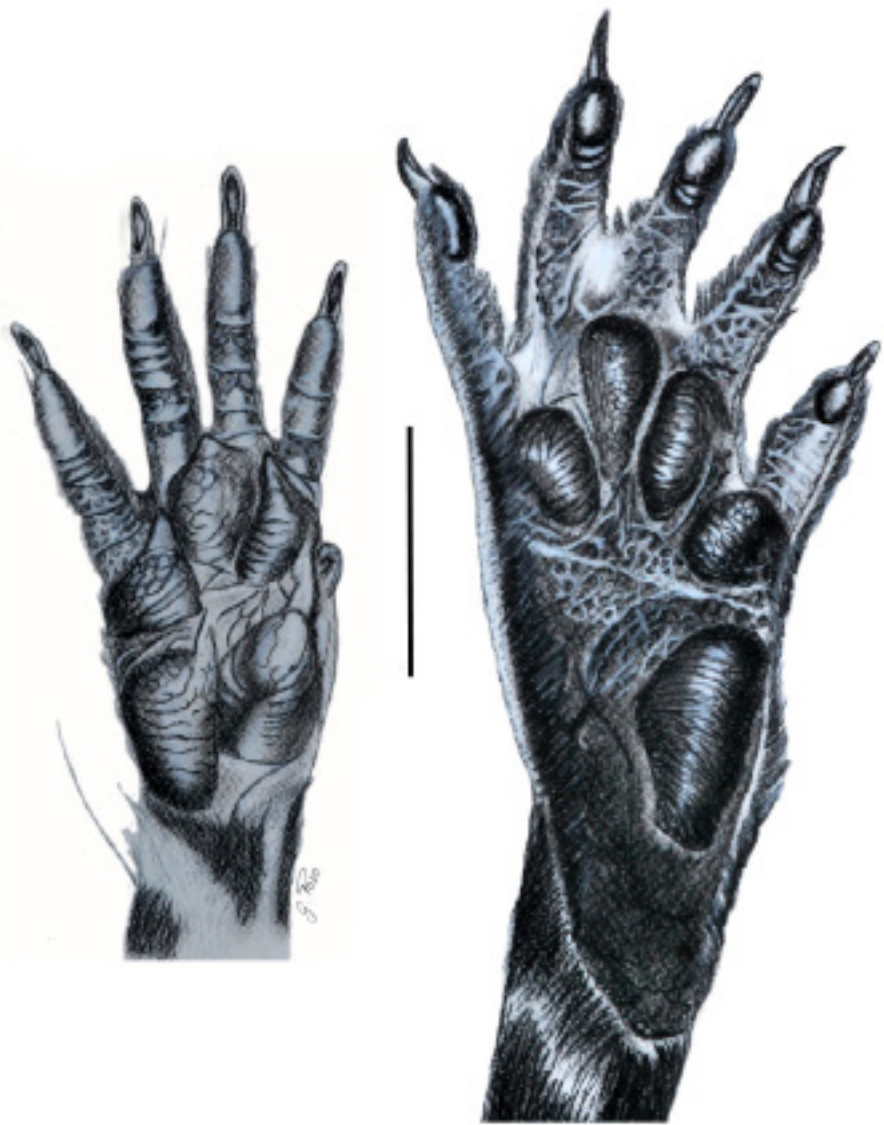

Figure 5. Palmar view of the right front leg (left) and plantar view of the right hind leg (right) of Ichthyomys stolzmanni (DMMECN 4,914). Bar $=10 \mathrm{~mm}$.

\section{Discussion}

Traditionally, the population of I. stolzmanni of Ecuador was considered as a single subspecies, I. s. orientalis, that differs from the typical Peruvian form based on the metacarpal coloration (e. g., Cabrera 1961; Voss 1988). However, the I. stolzmanni specimen (DMMECN 4,914) collected at the Jurumbuno river, although matching the majority of cranial and body characters reported by Voss (1988), differs from the specimens previously reported for Ecuador (Anthony 1923; Voss 1988) and Peru (Thomas 1893; Voss 1988; Pacheco and Ugarte-Núñez 2011; Voss 2015), which show a markedly bicolored tail. The specimen examined (DMMECN 4,914) has a bicolored tail to the medial part, while the posterior half is uniformly dark (a character not previously recorded in Ichthyomys). Other species of Ichthyomys (I. hydrobates, I. pittieri and I. tweedii) usually show a uniformly dark tail. Additional specimens should be collected from localities to fill the gap of nearly 1,000 kilometers between the Ecuadorian and Peruvian localities, in order to assess withinand between-population variation patterns in tail coloration.

The stomach contents of I. stolzmanni from the Jurumbuno river evidenced the presence of insects, shrimp and isopods; this finding is partly consistent with the stomach content reported for other specimens of this species (Voss et al. 1982; Voss 1988; Santillán and Segovia 2013). The finding of the isopod Artystone trisibia in the stomach content of the rat is unusual, as these organisms in the Jurumbuno river are parasites that have been reported inside benthic fish (Anaguano-Yancha and Brito 2015; Anaguano-Yancha and Brito in prep.); however, the stomach contents of the rat showed no evidence of fish. In southern Peru, l. stolzmanni feeds on fish and often preys on trout cultures (Pacheco and Ugarte-Núñez 2011). However, in the locality reported here, despite its proximity to tilapia culture ponds, local people are unaware of the predation of their fish by the rat, although they mention attacks by the water opossum (Chironectes minimus). 
In Ecuador, the known distribution of I. stolzmanni was limited to only two localities, the provinces of Napo and Zamora Chinchipe (Anthony 1923; Voss 1988; Pacheco 2003; Tirira 2007). The specimen reported here represents the third locality for Ecuador and the first for the province of Morona Santiago, 40 years after the previous collection.

Ichthyomys stolzmanni is considered to be a rare and little known rat due to the conventional sampling methods used to date (Pacheco and Ugarte-Núñez 2011). I. stolzmanni is poorly represented in scientific collections and its distribution is little known. For this reason, and given that the knowledge about non-flying small mammals in Ecuador is still fragmented, further sampling efforts are needed in the eastern foothills of the country, an area considered as an important diversity and endemism zone (Myers et al. 2000; Prado et al. 2014; Maestri and Patterson 2016).

\section{Acknowledgments}

We are grateful to D. Tirira and J. Ugarte-Núñez, who provided information and photographs of $I$. stolzmanni. C. Reyes collaborated in the design of Figure 1. D. Padilla identified part of the stomach contents. G. D'Elía and two anonymous reviewers made valuable comments that improved the quality of the manuscript. The collection was approved by the research license $\mathrm{N}^{\circ}$. 05-2014-I-BDPMS/MAE granted by the Ministry of Environment of Morona Santiago. This manuscript was translated by Maria Elena Sánchez Salazar with support of THERYA through a CONACYT grant.

\section{Literature Cited}

Albuja, L., A. Almendáriz, R. Barriga, L. D. Montalvo, F. Cáceres, and J. L. Román. 2012. Fauna de Vertebrados del Ecuador. Instituto de Ciencias Biológicas, Escuela Politécnica Nacional. Quito, Ecuador.

Anaguano-Yancha, F., And J. Brito. 2015. Parasitismo de Riggia sp. (Isopoda: Cymothoidae) en dos especies de peces Chaetostoma sp. y Rhamdia quelen del suroriente del Ecuador. Avances en Ciencias e Ingenierías 7:B13-B16.

Anthony, H. E. 1923. Preliminary report on Ecuadorean mammals. American Museum Novitates 55:1-14.

Barriga, R. 2012. Lista de peces de agua dulce e intermareales del Ecuador. Revista Politécnica 30:83-119.

Brito, J., H. Orellana-Vásquez., H. Cadena-Ortiz., R. Vargas., G. Pozo-Zamora, and J. Curay. 2015. Mamíferos pequeños en la dieta de la lechuza Tyto alba (Strigiformes: Tytonidae) en dos localidades del occidente de Ecuador, con ampliación distribucional de Ichthyomys hydrobates (Rodentia: Cricetidae). Papéis Avulsos de Zoologia 55:261-268.

Cabrera, A. 1961. Catálogo de los mamíferos de América del Sur. Revista del Museo Argentino de Ciencias Naturales "Bernardino Rivadavia" 4:309-732.

García, F. J., M. Machado, M. I. Delgado-Castillo, L. Aular, and Y. Mújica. 2012. Nuevo registro de Ichthyomys pittieri (Rodentia: Cricetidae) para la Cordillera de la Costa Central de Venezuela con notas sobre su historia natural y distribución. Mastozoología Neotropical 19:303-309.

Maestri, R., ANd B. D. Patterson. 2016. Patterns of species richness and turnover for the South American rodent fauna. PLoS ONE 11:1-18.

Myers, N., R. A. Mittermeier, C. G. Mittermeier, G. A. B. da FonseCA, And J. Kent. 2000. Biodiversity hotspots for conservation priorities. Nature 403:853-858.

Pacheco, V. 2003. Phylogenetic analyses of the Thomasomyini (Muroidea: Sigmodontinae) based on morphological data. PhD. dissertation. The City University New York. New York, U. S. A.

Pacheco, V., ANd J. Ugarte-Núñez. 2011. New records of Stolzmann's fish-eating rat Ichthyomys stolzmanni (Cricetidae, Sigmodontinae) in Peru: A rare species becoming a nuisance. Mammalian Biology 76:657-661.

Prado, J. R., P. G. G. Brennand, L. P. Godoy, G. S. Libardi, E. F. Abreu-Júnior, P. R. O. Roth, E. A. Chiquito, and A. R. Percequillo. 2014. Species richness and areas of endemism of Oryzomyine rodents (Cricetidae, Sigmodontinae) in South America: an NDM/VNDM approach. Journal of Biogeography 42:540-551. 
Santillán, V., and E. Segovia. 2013. Primer registro de la rata cangrejera de Tweedy Ichthyomys tweedii (Sigmodontinae: Ichthyomyini) en la provincia del Azuay, Ecuador. Mastozoología Neotropical 20:421-424.

Tномаs, O. 1893. On some mammals from central Peru. Proceedings Zoological Society of London 23:333-341.

TiriRA, D. 2007. Guía de campo de los Mamíferos del Ecuador. Ediciones Murciélago Blanco. Quito, Ecuador.

TiRIRA, D. (ED.). 2011. Libro Rojo de los mamíferos del Ecuador, segunda edición. Fundación Mamíferos y Conservación, Pontificia Universidad Católica del Ecuador y Ministerio del Ambiente del Ecuador, publicación especial sobre los mamíferos del Ecuador 8. Quito, Ecuador.

Voss, R. S., J. L. Silva, ANd J. A. VAldes. 1982. Feeding behavior and diets of Neotropical water rats, genus Ichthyomys Thomas, 1893. Zeitschrift fur Saugetierkunde 47:364-369.

Voss, R. 1988. Systematics and Ecology of Ichthyomyne Rodents (Muroidea): Patterns of morphological Evolution in a small Adaptive Radiation. Bulletin of the American Museum of Natural History 188:259- 493.

Voss, R. S. 2015. Tribe Ichthyomyini Vorontsov, 1959. Pp: 279-291, en Mammals of South America. Volume 2, Rodents. (Patton, J. L., U. F. J. Pardiñas, y G. D’Elía, eds.). The University of Chicago Press. Chicago, U.S. A.

Submitted: May 30, 2016

Reviewed: July 18, 2016

Accepted: August 28, 2016

Associated editor: Guillermo D'Elía 